\title{
Modelling of windmill induction generators in dynamic simulation programs
}

\author{
Akhmatov, Vladislav; Knudsen, Hans
}

Published in:

Proceedings of International IEEE Power Tech Conference

Link to article, DOI:

10.1109/PTC.1999.826539

Publication date:

1999

Document Version

Publisher's PDF, also known as Version of record

Link back to DTU Orbit

Citation $(A P A)$ :

Akhmatov, V., \& Knudsen, H. (1999). Modelling of windmill induction generators in dynamic simulation programs. In Proceedings of International IEEE Power Tech Conference IEEE.

https://doi.org/10.1109/PTC.1999.826539

\section{General rights}

Copyright and moral rights for the publications made accessible in the public portal are retained by the authors and/or other copyright owners and it is a condition of accessing publications that users recognise and abide by the legal requirements associated with these rights.

- Users may download and print one copy of any publication from the public portal for the purpose of private study or research.

- You may not further distribute the material or use it for any profit-making activity or commercial gain

- You may freely distribute the URL identifying the publication in the public portal

If you believe that this document breaches copyright please contact us providing details, and we will remove access to the work immediately and investigate your claim. 


\section{Modelling of Windmill Induction Generators in Dynamic Simulation Programs.}

\author{
Vladislav Akhmatov \\ vay@nesa.dk \\ Technical University of Denmark \\ Lyngby, Denmark
}

\begin{abstract}
For AC networks with large amounts of induction generators - in case of e.g. windmills - the paper demonstrates a significant discrepancy in the simulated voltage recovery after faults in weak networks, when comparing result obtained with dynamic stability programs and transient programs, respectively with and without a model of the mechanical shaft. The reason for the discrepancies are explained, and it is shown that the phenomenon is due partly to the presence of DC offset currents in the induction machine stator, and partly to the mechanical shaft system of the windturbine and the generator rotor. It is shown that it is possible to include a transient model in dynamic stability programs and thus obtain correct results also in dynamic stability programs. A mechanical model of the shaft system has also been included in the generator model.
\end{abstract}

Keywords: Induction machines, transient models, dynamic models, PSS/E, EMTP, ATP, MODELS, windmills, shaft models.

\section{INTRODUCTION}

Wind power has gained importance in Denmark over the last years, and in the years to come it is going to play an even more important role in the electric power supply. In the east Danish power system the expected installed capacity in the year 2008 is approx. $1000 \mathrm{MW}$, and the long term perspective is above $2000 \mathrm{MW}$ in the year 2030 , primarily in the form of new off-shore wind farms.

Preliminary studies using a dynamic stability program have indicated, that the combination of a weak $A C$ network and a high amount of power from the windmills will make voltage collapse the predominant dimensioning factor in this region in the years to come. However, recent investigations have indicated, that exactly the induction generator models in dynamic stability programs have a flaw, which may be of importance, when used in connection with windmills.

\section{RESULTS}

A full transient model of an induction generator - including a representation of the stator DC offset - and with a shaft model has been implemented in the dynamic stability program PSS/E. Comparative simulations have been performed using the same network and simulating the same event, but using four different induction generator models:

1) a dynamic model with a shaft model,

2) a transient model with a shaft model,

3) a dynamic model with a lumped rotor mass, and

4) a transient model with a lumped rotor mass.

The simulation results are shown in Fig. 1.

\author{
Hans Knudsen \\ hak@nesa.dk \\ NESA Transmission Planning, \\ Denmark
}

As can be seen the results for the cases 3 and 4 (with lumped rotating masses) are almost identical.

The results for the cases 1 and 2 (with shaft models) are however remarkable. They differ both from each other and from the results obtained with the lumped mass models.

The oscillation in the machine terminal voltage is caused by the mechanical oscillation of the small generator rotor against the larger inertia of the windturbine. The presence of these oscillations in the $\mathrm{AC}$ voltages means that the mechanical shaft oscillation may excite other modes of oscillation in the rest of the AC system; e.g. power oscillations which normally have low frequencies.

\section{CONCLUSIONS}

Investigations have shown that stator DC offset in an induction machine is significant for a correct representation of the rotor speed and thereby also for reactive power consumption and machine terminal voltage.

Investigation have also shown that the shaft of a windmill has a significant impact on the dynamic behaviour of the windmill. This is due to the fact that the reactive consumption of an induction machine is dependant on rotor speed.

The results clearly show that windmill induction generator models should have both a representation of the mechanical shaft and of the stator transients such as DC offset in order to produce reliable simulation results in dynamic simulation programs.

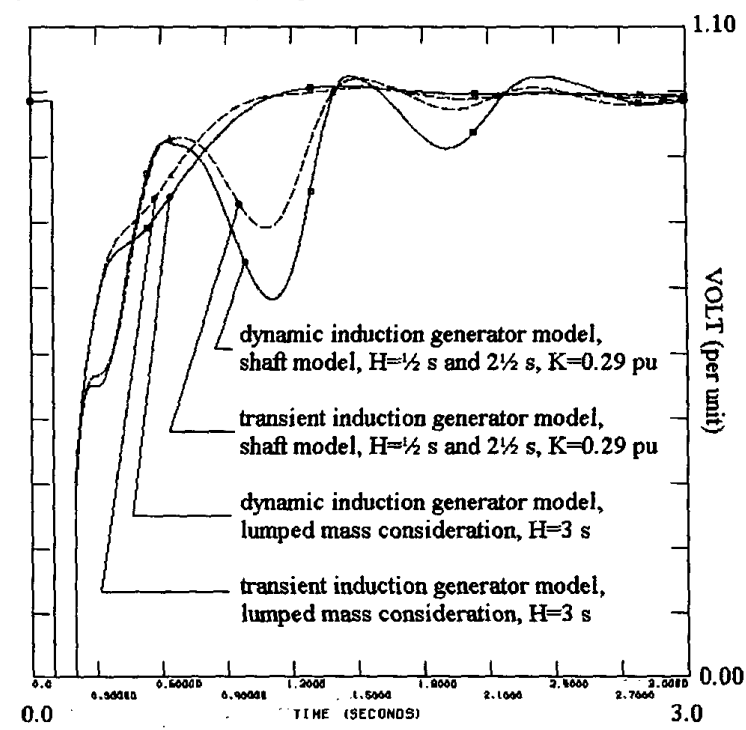

Fig. 1: Comparison of various models - voltages 